\title{
Die persepsies en houdings van gelowige jonggetroude egpare oor seksuele intimiteit in die huwelik
}

\begin{tabular}{|c|c|}
\hline \multicolumn{2}{|c|}{$\begin{array}{l}\text { Authors: } \\
\text { Rinee Pretorius (née Viljoen) }{ }^{1} \\
\text { Christiaan A. Venter } \\
\text { Barend J. de Klerk }\end{array}$} \\
\hline \multicolumn{2}{|c|}{$\begin{array}{l}\text { Affiliations: } \\
{ }^{1} \text { School for Ecclesiastical } \\
\text { Sciences, North-West } \\
\text { University, South Africa }\end{array}$} \\
\hline \multicolumn{2}{|c|}{$\begin{array}{l}{ }^{2} \text { School for Psycho-Social } \\
\text { Behavioural Sciences, North- } \\
\text { West University, South Africa }\end{array}$} \\
\hline \multicolumn{2}{|c|}{$\begin{array}{l}\text { Correspondence to: } \\
\text { Chris Venter }\end{array}$} \\
\hline \multicolumn{2}{|c|}{$\begin{array}{l}\text { Email: } \\
\text { chris.venter@nwu.ac.za }\end{array}$} \\
\hline \multicolumn{2}{|c|}{$\begin{array}{l}\text { Postal address: } \\
\text { Private Bag X6001, } \\
\text { Potchefstroom 2520, } \\
\text { South Africa }\end{array}$} \\
\hline \multicolumn{2}{|c|}{$\begin{array}{l}\text { Dates: } \\
\text { Received: } 31 \text { Jan. } 2012 \\
\text { Accepted: } 20 \text { June } 2012 \\
\text { Published: } 22 \text { May } 2013\end{array}$} \\
\hline \multicolumn{2}{|c|}{$\begin{array}{l}\text { How to cite this article: } \\
\text { Pretorius, R., Venter, C.A. } \\
\text { \& De Klerk, B.J., } 2013 \text { 'Die } \\
\text { persepsies en houdings } \\
\text { van gelowige jonggetroude } \\
\text { egpare oor seksuele } \\
\text { intimiteit in die huwelik', } \\
\text { In die Skriflig/In Luce Verbi } \\
47(1), \text { Art. \#71, } 14 \text { pages. } \\
\text { http://dx.doi.org/10.4102/ } \\
\text { ids.v47i1.71 }\end{array}$} \\
\hline \multicolumn{2}{|c|}{$\begin{array}{l}\text { Copyright: } \\
\text { (C) 2013. The Authors. } \\
\text { Licensee: AOSIS } \\
\text { OpenJournals. This work } \\
\text { is licensed under the } \\
\text { Creative Commons } \\
\text { Attribution License. }\end{array}$} \\
\hline \multicolumn{2}{|l|}{ Read online: } \\
\hline 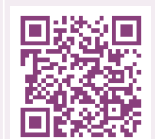 & $\begin{array}{l}\text { Scan this QR } \\
\text { code with your } \\
\text { smart phone or } \\
\text { mobile device } \\
\text { to read online. }\end{array}$ \\
\hline
\end{tabular}

Hierdie artikel is gebaseer op empiriese navorsing om die persepsies en houdings van gelowige, jonggetroude egpare oor seksuele intimiteit in die huwelik na te vors. Daar is gefokus op hoe die egpare die verhouding sien waarbinne seksuele intimiteit geniet en beleef mag word; wat na hulle mening die man en vrou se plig is rakende die seksuele; wat hulle persepsies is oor die vryheid wat seksuele intimiteit binne die huwelik bied, en wat eksklusiwiteit ten opsigte van seksuele intimiteit binne die huwelik vir elkeen van hulle beteken. 'n Kwalitatiewe navorsingsontwerp is gebruik en sewe gelowige egpare wat minder as twee jaar getroud was $(N=11)$, het aan die navorsing deelgeneem. Die navorsingsdata is uit ' $n$ kort vraelys verkry en deur semigestruktureerde onderhoude wat met sommige van die deelnemers gevoer is. ' $n$ Ryke oes van data is verkry en 'n hele aantal temas is identifiseer. Hierdie temas sluit goed aan by die basisteoretiese en metateoretiese perspektiewe wat as onderbou vir hierdie navorsing gedien het.

The perceptions and attitudes of religious newlywedded couples regarding sexual intimacy in the marriage. This article is based on empirical research done to explore the perceptions and attitudes of religious newlywedded couples regarding sexual intimacy in the marriage. The research focused on how the couples regard a relationship in which sexual intimacy can be enjoyed and experienced; what, in their opinion, the husband and the wife's responsibilities are towards each other regarding sex; what their perceptions are about the freedom that sexual intimacy offers in marriage, and what marital exclusivity regarding sexual intimacy means to each of the participants. A qualitative research design was used and seven religious couples that were married less than two years $(N=11)$ participated in this research. The research data was obtained by using a short questionnaire and semi-structured interviews which were conducted with some of the participants. Rich data was obtained and many themes were identified. These themes correspond well with the basic-theoretical and meta-theoretical perspectives that served as underpinning for the research.

\section{Inleiding}

Die term intimiteit het sy oorsprong in die Latynse woord intimus wat 'innigste' of 'diepste' beteken (Masters, Johnson \& Kolodny 1992:310). Intimiteit kan gedefinieer word as 'n proses waarbinne twee persone wat vir mekaar omgee so vrylik moontlik met mekaar die uitruil van gevoelens, gedagtes en handelinge deel (Masters et al. 1992:310). Volgens Schaefer en Olson (1981:47), is daar verskeie soorte intimiteit, naamlik emosionele, sosiale, seksuele, intellektuele, rekreatiewe en religieuse of spirituele intimiteit. Seksuele of fisiese intimiteit verwys na die ervaring en deel van algemene affeksie en/of seksuele aktiwiteit (Chapman 2005:2).

Alhoewel seksuele intimiteit as sodanig nie 'n bybelse term is nie, kan die belangrike plek wat dit in die huweliksverhouding inneem, afgelei word uit Skrifgedeeltes rakende intimiteit in die konteks van die Christelike huwelik. Dit is daardie besondere mooi en intieme verhouding wat eie is aan die verhouding tussen man en vrou, in die privaatheid van liefde. Dit is heilig, aangesien God dit bedoel het juis vir hierdie verhouding, vir wedersydse aanvulling, emosionele sekuriteit en hartstog, asook fisieke eenwording en voortplanting (Craig \& Stander 2008:9; LaHaye \& LaHaye 2003:11; Louw 2004:139).

Die kwaliteit van die seksuele intimiteit binne die huwelik is dikwels 'n aanduiding van die kwaliteit van die huweliksverhouding, aangesien daar 'n sterk verband tussen seksuele interaksie en huwelikstevredenheid is (Lieser et al. 2007:374). In die beginfase van die huwelik word aanpassingsprobleme dikwels ervaar vanweë onrealistiese verwagtings oor die huwelik, ontnugtering ten opsigte van seks, waninligting oor intimiteit en veranderende rolle (Collins 2005:259), negatiewe houdings teenoor seks en geloofsoortuigings wat sekere seksuele aktiwiteite verbied (Collins 2005:305). Die wanopvatting dat die bybelse siening van seksualiteit vuil en 
sondig is, is ook 'n groot oorsaak van seksuele disfunksie (Casaleggio \& Van Rensburg 2002:372).

Vanweë die opsigtelike leemte wat daar in die navorsingsliteratuur bestaan oor gelowige jonggetroude egpare se persepsies en houdings oor seksuele intimiteit binne die huwelik, word sodanige navorsing as uiters noodsaaklik beskou. Die huidige verkennende studie is 'n poging om deur middel van kwalitatiewe navorsing met ' $n$ klein aantal deelnemers, genoemde leemte te ondervang.

'n Basisteoretiese ondersoek na bybelse riglyne is ingestel waarna metateoretiese navorsing van naasliggende wetenskappe gedoen is. Die struktuur van Zerfass se model vir die Praktiese Teologie (De Wet 2009:10) is tydens hierdie navorsing gebruik. Zerfass se model behels 'n hermeneutiese wisselwerking tussen basisteorie, metateorie en praktykteorie.

\section{Basisteoretiese perspektiewe vanuit die Bybel met betrekking tot seksuele intimiteit in die huwelik}

'n Basisteorie is ontwerp vanuit die beginsels wat die Bybel rakende intimiteit bied in die konteks van die Christelike huwelik in Efesiërs 5:21-33, 1 Korintiërs 7:3-5, Hooglied 1-8 en Spreuke 5:15-die 19. In al hierdie Skrifgedeeltes gaan dit eerstens oor die man en vrou se verhouding met en liefde vir God. Vier hoofpunte is hieruit geïdentifiseer waarin die bybelse voorskrifte saamgevat kan word. Elkeen word vervolgens kortliks aangedui.

\section{Die verhouding waarbinne die gelowige egpaar seksuele intimiteit mag geniet en uitleef}

'n Eksegese van Efesiërs 5:21-33 wys daarop dat die man en die vrou se nuwe lewe in Christus en onder beheer van die Heilige Gees in hulle huwelik gestalte moet kry. Tussen die man en die vrou behoort daar geestelike intimiteit te wees, aangesien die huweliksverhouding 'n weerspieëling van Jesus Christus se verhouding met sy kerk moet wees (De Klerk 2001:101; Ney 2002:32). Die gelowige vrou word opgeroep om aan haar man onderdanig te wees deur hom te ondersteun en te dien soos wat die kerk Christus dien. Die man word opgeroep om sy vrou lief te hê soos sy eie liggaam, om homself op te offer, haar hoër as homself te ag en haar te versorg soos wat Christus met sy kerk doen.

Uit bogenoemde kan afgelei word dat die huwelik sekuriteit skep, 'n atmosfeer waarbinne die persone een word met mekaar in die uitleef van hulle seksualiteit. In so 'n verhouding behels sekuriteit onder meer betrokkenheid by mekaar, 'n veilige ruimte en verantwoordelike omgang met die seksuele.

\section{Die opdrag wat die Bybel gee aangaande die man en vrou se plig teenoor mekaar rakende die seksuele}

In 1 Korintiërs 7:3-5 wys Paulus besonderlik daarop dat die huwelik as 'n seksuele verhouding beskou word wat vir die welsyn van die egpaar bedoel is. Ook dat die man en die vrou ' $n$ verpligting teenoor mekaar het om mekaar se seksuele drange te bevredig (Craig \& Stander 2008:40; De Klerk 1997:44). God het die huwelik vir die man en die vrou ingestel om een te word in die huwelik; daarom behoort die man en die vrou se liggame nie aan hulself nie, maar aan mekaar. Juis omdat hulle aan mekaar behoort, rus daar 'n huweliksplig op elkeen om sy maat nie seksuele intimiteit te ontneem nie. Inteendeel, elkeen moet die ander se behoeftes ken en bevredig op 'n liefdevolle wyse (1 Kor 7:5) om die huwelik teen die verleiding van Satan te beskerm.

Uit bogenoemde kan afgelei word dat seks deur God as iets goed geskep is, uitsluitlik vir die huwelik. God het dit so bestem dat hulle na mekaar sal hunker, hulself vrylik met mekaar sal deel, saam genot en plesier sal ervaar, maar nooit ten koste van die ander party nie.

\section{Die prag, vryheid en misterie wat seksuele intimiteit vir die gelowige egpaar binne die huwelik inhou}

Dit blyk uit Hooglied dat seksuele gevoelens tot die skepping van God behoort (vgl. Hoogl 1:2, 4; 2:4-5; 5:4, 6, 8; 7:10, 1112). Die seksuele intimiteit van die man en die vrou binne die huwelik is iets moois en spesiaals. Hier hoort geen skaamte nie, maar slegs bewondering vir mekaar se liggame en die genieting van mekaar se liefkosing, wat óf deur die man, óf deur die vrou geïnisieer kan word. Hierdie liefde en seksuele intimiteit maak soveel bewondering vir die man en die vrou in mekaar wakker dat hulle gedurig bymekaar wil wees.

Hooglied toon aan dat daar bykans oneindige vryheid binne die huwelik aangaande seksuele intimiteit bestaan. Hieruit kan afgelei word dat die fisiese aantrekkingskrag en liefde tussen die man en die vrou in die huwelik toelaatbaar is en dat dit opgewondenheid en erotiese opwekking tot gevolg behoort te hê. Die man en die vrou mag mekaar se liefkosing en liefde geniet en daar behoort nie enige terughoudende skaamte te wees nie. In reaksie op bogenoemde erotiese en seksuele opwekking, is dit vir albei geoorloof om die inisiatief in hierdie verband te neem en die ander persoon uit te nooi. Die man en die vrou eer God wanneer hulle mekaar liefhet en die prag, vryheid en misterie geniet wat seksuele intimiteit binne die huwelik inhou.

\section{Die eksklusiwiteit en skoonheid van seksuele intimiteit binne die huwelik}

In Spreuke 5:15-19 is dit duidelik dat die man hom in sy eie vrou se liefde moet verbly. Daar is ook 'n ernstige waarskuwing aan getroudes om nie elders, dit wil sê buite die huwelik, bevrediging te soek nie, maar om God vir die eie man of vrou dankbaar te wees Hierdie eksklusiwiteit word deur Rosenau (2002:17) met die metafoor van 'n omheinde tuin verduidelik. Die omheining wat God daar stel is vir die beskerming van die pragtige huweliks- en seksuele tuin.

In die huwelik is daar skoonheid en vreugde in seksuele intimiteit. Die man en die vrou moet mekaar geniet en 
mekaar seksueel bevredig. Verder behoort hulle deur mekaar se liefde bedwelmd te wees. Hierdie besondere eienskap van die huweliksdaad tussen die man en die vrou kan beskryf word as die verhewe, intieme versmelting van verstand, hart, emosies en liggaam in 'n hartstogtelike, opwellende klimaks wat die deelhebbers in 'n golf van onskuldige ontspanning omvou en hulle liefde ten volle ontplooi (LaHaye \& LaHaye 2003:20). Die man en die vrou word albei angemoedig om hulle lewe lank bevrediging, plesier, vreugde en kameraadskap by mekaar te vind.

Hieruit kan afgelei word dat seksuele omgang nooit vir oorreding of manipulasie van die huweliksmaat gebruik mag word nie. Egbreuk is 'n omvattende begrip wat behalwe vir seksuele ontrouheid aan 'n eggenoot ook ander aspekte insluit, soos dat 'n man of vrou ontrou kan wees deur hulle beroep, kinders of selfs die kerk bo huweliksvoorregte en huweliksverpligtings te stel.

\section{Metateoretiese perspektiewe vanuit die Psigologie en die Sosiologie met betrekking tot seksuele intimiteit in die huwelik}

\section{Psigologiese en sosiologiese perspektiewe oor die huweliksverhouding as 'n verhouding waarbinne seksuele intimiteit geniet en uitgeleef mag word}

Seksuele intimiteit is 'n belangrike psigologiese taak wat tussen die huweliksmaats onderhandel moet word. Dit moet binne 'n milieu van veiligheid, intimiteit, nabyheid en emosionele versorging plaasvind (Brown \& Brown 2002:12-27). Uit die vakliteratuur van die Psigologie en die Sosiologie blyk dat seksuele intimiteit nie noodwendig binne die grense van die huwelik hoef plaas te vind nie; inteendeel, dit word as 'n sentrale faktor in huweliks-, sowel as voorhuwelikse verhoudings beskou (Haavio-Mannila \& Kontura 1997:401; Rodgers 1973:24).

\section{Psigologiese en sosiologiese perspektiewe aangaande die man en die vrou se plig teenoor mekaar rakende die seksuele}

Alhoewel daar nie spesifiek na die man en die vrou se plig teenoor mekaar aangaande die seksuele in die huwelik verwys word nie, word die belangrikheid van seksuele intimiteit beklemtoon (Brown \& Brown 2002:12; Epstein et al. 2003:591). Wallerstein (aangehaal deur Brown \& Brown 2002:22) stel dat wanneer 'n egpaar sáám seksuele genot ervaar, dit hulle persepsies en fantasieë oor mekaar verbreed en albei se selfbeeld positief beïnvloed. Navorsing het ook getoon dat ' $n$ bevredigende en vervulde seksuele verhouding 'n deurslaggewende rol speel in die inrigting en instandhouding van'ngelukkige, bevredigendeenlangdurige huwelik (Litzinger \& Gordon 2005:409; Holtzworth-Munroe \& Jacobson 1991:100; Rosen \& Bachmann 2008:291; Sprecher 2002:194). Talle outeurs beklemtoon die positiewe rol wat kommunikasie ten opsigte van huweliksmaats se seksuele intimiteit en seksuele tevredenheid kan speel (Brown \&
Brown 2002:22-23; Litzinger \& Gordon 2005:412; Epstein et al. 2003:585; Holtzworth-Munroe \& Jacobson 1991:101). Dit word beklemtoon dat die man en die vrou die kapasiteit moet hê om aanpasbaar en buigsaam te wees.

Dit blyk dat die stereotipiese siening van die man as die hoof van die huishouding en die vrou as onderdanig aan haar man al hoe meer aan die kwyn is (Chell 2001:33; HoltzworthMunroe \& Jacobson 1991:102). In die meeste domeine van die samelewing het die man en die vrou reg en aanspraak op gelykheid en daarom is dit byna vanselfsprekend dat geen spesifieke huweliksplig op die man of die vrou afgedwing kan word nie.

Daar bestaan ook groot verskille ten opsigte van die seksuele behoeftes van mans en vroue. Waar die tydsduur en die begeerte na gereeldheid van die seksuele omgang byvoorbeeld vir mans baie belangrik is, is die teerheid, aanraking en koestering weer vir vroue belangrik (Santtila et al. 2008:32). Dit is daarom belangrik dat egliede mekaar in hierdie verband respekteer.

\section{Psigologiese en sosiologiese perspektiewe oor die vryheid, prag en misterie wat seksuele intimiteit vir die egpaar inhou}

Die mens se hunkering na seks en seksuele intimiteit is 'n fundamentele menslike eienskap, net soos honger of dors. Juis as gevolg van hierdie fundamentele status is dit sentraal tot elke huweliksverhouding, want dit is ' $n$ bron van byna oneindige geluk en vervulling (Hawkes 2002:6). Seksuele intimiteit is ' $n$ sensuele ervaring met 'n groot mate van affektiewe betrokkenheid (Hawkes 2002:6).

Die tendens in die samelewing is dat daar al hoe meer vryheid ten opsigte van seksuele praktyke, oriëntasie, gewoontes en begeertes bestaan (Hawkes 2002:146). Gedurende die laaste paar dekades het ' $n$ aansienlike skuif plaasgevind aangaande die vryheid van seksualiteit - vanaf seks as 'n gevaar na seks vir plesier.

Soos vroeër aangedui (vgl. 'Psigologiese en sosiologiese perspektiewe aangaande die man en die vrou se plig teenoor mekaar rakende die seksuele') speel 'n vervulde seksuele verhouding 'n belangrike rol in persone se huweliksverhouding. Egliede wat 'n positiewe houding teenoor mekaar inneem en oor goeie kommunikasievaardighede beskik, se verhouding kan tot 'n groot mate verdiep. Die samehorigheidsgevoel en intimiteit (wat seksuele intimiteit insluit) sal toenemend gevestig word en sowel die man as die vrou sal toenemend voel dat hulle huweliksmaat hulle verstaan en ondersteun (Venter 1996:72).

\section{Psigologiese en sosiologiese perspektiewe oor die eksklusiwiteit en die skoonheid van seksuele intimiteit binne die huwelik}

Vanweë die tendens dat daar in die samelewing al hoe meer vryheid ten opsigte van seksuele praktyke bestaan (Hawkes 2002:146), het talle veranderings plaasgevind op die terreine 
van buite-egtelike seks, egskeiding, die vroeër aanvang van seksuele aktiwiteit en die beskikbaarheid en gebruik van voorbehoedmiddels (Hawkes 2001:53). Eksklusiwiteit in die betekenis dat die man en die vrou hulself tot die huweliksluiting rein hou en ook daarná aan mekaar getrou bly, is beslis nie meer die norm in die samelewing nie.

Dit blyk egter dat eksklusiwiteit ten opsigte van seksuele intimiteit wel waarde het. Liefde impliseer eksklusiwiteit ten opsigte van intimiteit, seksualiteit, verbintenis en die bereidheid om enigiets vir die maat te gee (Bergner 2005:428). Volgens strukturele gesinsterapeute is dit belangrik dat die huwelik-subsisteem onder andere teen invloede van buite beskerm moet word wat die huweliksverhouding kan ondermyn (Bevcar \& Bevcar 2002:178). Hierdie invloede van buite sluit uiteraard ook eksklusiwiteit rakende seksuele intimiteit in. Uit Brown en Brown (2002:27) se gevolgtrekkings oor die eienskappe van suksesvolle huwelike kan afgelei word dat seksuele eksklusiwiteit in die huwelik uiters belangrik is.

\section{Die empiriese navorsing Doel}

Die doel van hierdie navorsing was om die persepsies en houdings van gelowige, jonggetroude egpare aangaande seksuele intimiteit in die huwelik na te vors, betreffende die verhouding waarbinne seksuele intimiteit geniet en uitgeleef mag word; die man en die vrou se plig teenoor mekaar rakende die seksuele; die vryheid wat seksuele intimiteit binne die huwelik inhou; en die eksklusiwiteit van seksuele intimiteit binne die huwelik.

\section{Navorsingsontwerp}

Kwalitatiewe navorsing is gebruik, want hierdie metode is geskik om die gevoelens, ervarings, sosiale situasies of verskynsels soos wat dit in die wêreld voorkom, te bestudeer (Terre Blanche, Durrheim \& Painter 2006:287).

\section{Deelnemers}

Vanweë die aard en doelstellings van hierdie navorsing is slegs gelowige, jonggetroude (minder as twee jaar getroud), heteroseksuele egpare by die navorsing betrek. 'n Doelgerigte steekproef is dus gebruik (vgl. Uys \& Puttergill 2003:109).

Weens praktiese oorwegings is slegs egpare van verskillende kerkdenominasies in Potchefstroom by die navorsing betrek. Sewe egpare het in die navorsing belanggestel, maar net 11 van die 14 persone het deelgeneem, sewe vroue en vier mans. Die deelnemers was gemiddeld een jaar en vyf maande getroud; die spanwydte van die tydsduur wat hulle getroud was, was tussen een jaar een maand en twee jaar; hulle gemiddelde ouderdom was 27 jaar en 5 maande; die oudste deelnemer was 32 jaar en 7 maande, en die jongste was 25 jaar en 2 maande; al die deelnemers was blank en Afrikaanssprekend, met die uitsondering van een Engelssprekende vrou. Geen van die egpare het voor hulle huwelik saamgewoon nie en een van die deelnemers was vroeër vir 'n tydperk van drie jaar getroud en toe geskei. Al die deelnemers was meelewende lidmate van erkende kerke.

\section{Data-insameling}

Die data-insamelingsproses het bestaan uit die voorbereidingsfase, die onderhoudfase en die naonderhoudfase (Poggenpoel 2003:146). Tydens die voorbereidingsfase is die predikante van verskillende denominasies in Potchefstroom deur die eerste outeur genader en oor die beplande navorsing ingelig. Die predikante het belangstellende egpare in hulle gemeentes geïdentifiseer wat deur die eerste outeur geskakel is. Die navorsingsproses is aan hulle verduidelik en hulle is daarvan verseker dat deelname aan die navorsing vrywillig is, dat hulle inligting anoniem en vertroulik gehanteer sou word, en dat hulle in enige stadium van die proses kon onttrek sonder om redes daarvoor te verstrek (Hopf 2004:335; Poggenpoel 2003:146; Ryen 2004:231-232; Terre Blanche et al. 2006:72).

Voor die onderhoudfase het elke deelnemer ' $n$ kort vraelys ontvang wat hulle moes invul en aan die eerste outeur terugbesorg. Die volgende vrae is gevra: Wat is volgens $\mathrm{u}$ belangrike kenmerke in ' $\mathrm{n}$ egpaar se verhouding om seksuele uitlewing en genieting daarvan te verseker?; Is seks in die huwelik 'n opdrag, en daarom 'n verpligting wat die huweliksmaats teenoor mekaar het?; Kan die man en/of vrou daarop aanspraak maak en dit afdwing?; Wat is volgens $\mathrm{u}$ die eienskappe van 'n gesonde seksuele verhouding?; Wat is geoorloof rakende die seksuele in die huwelik?; Tot watter mate is eksperimentering geoorloof? Waarom?; Watter besondere bydrae lewer die seksuele komponent van julle huwelik tot julle huweliksverhouding?; en Watter beperkings plaas jou en jou huweliksmaat se seksuele verhouding op jou kontak met ander persone van die teenoorgestelde geslag, indien enige?

Elf vraelyste is terugontvang, sewe van vroue en vier van mans. 'n Week nadat die vraelyste terugontvang is, het die eerste outeur individuele, semigestruktureerde onderhoude (Poggenpoel 2003:148) met agt vrywillige deelnemers gevoer - vyf vroue en drie mans (die onderhoudfase). Tydens die onderhoude is die vrae van die kort vraelys as stimulusvrae gebruik en onduidelikhede op die ingevulde vraelyste is opgeklaar. Die onderhoude is met die deelnemers se toestemming met 'n digitale klankopnemer opgeneem (Poggenpoel 2003:147). Voor elke onderhoud is die deelnemers weereens van die anonimiteit en die vertroulikheid van hulle gesprekke verseker.

$\mathrm{Na}$ elke onderhoud (die na-onderhoudfase) het die onderhoudvoerder haar indrukke oor die onderhoud neergeskryf, asook haar belewenisse van die sessie. Sy het al die onderhoude getranskribeer (Kowal \& O'Connell 2004:248). Dit het haar nie net meer vertroud gemaak met die data en die analiseringsproses vergemaklik nie, maar het ook die geloofwaardigheid van die studie verhoog (Botes 2003:180). 


\section{Data-analise}

Die eerste outeur het die navorsingsdata aan die hand van die voorstelle van Schmidt (2004:254) en Terre Blanche et al. (2006:322) ontleed. Die data is indringend verken deur die herhaaldelike en noukeurige deurlees van die antwoorde op die vraelyste, die getranskribeerde onderhoude en haar notas (oop kodering). Daarna is die data kategoriaal georden (aksiale kodering) en sodoende is die temas vasgestel. $\mathrm{Na}$ die vasstelling van die temas is die data weer gelees en toepaslike uitsprake en/of geskrewe dele is gekies om die onderskeie temas mee te belig. Die Engelssprekende deelnemer se menings is na Afrikaans vertaal ten einde haar minder identifiseerbaar te maak. Die tweede outeur het ook die data gekodeer. Die data is verder geïnterpreteer en gevolgtrekkings is gemaak (selektiewe kodering).

\section{Vertrouenswaardigheid van die data}

Die geldigheid en betroubaarheid van die navorsing is verseker deur by Guba (aangehaal deur Shenton, 2004:63-71) se vier kriteria vir kwalitatiewe navorsing te hou, naamlik interne geldigheid, eksterne geldigheid, betroubaarheid en objektiwiteit.

Interne geldigheid is onder andere verseker deur die gebruikmaking van goed gevestigde navorsingsmetodes en verskeie data-insamelingsmetodes (triangulasie) (vgl. Botes 2003:181). Die tweede outeur - 'n ervare navorser op hierdie gebied - het die eerste outeur tydens die verloop van die navorsingsproses begelei. Eksterne geldigheid is verseker deur genoegsame inligting oor die veldwerk te voorsien om sodoende die lesers in staat te stel om dit op ander situasies toe te pas. Om die betroubaarheid van die studie te verhoog, is die navorsing breedvoerig gerapporteer ten einde toekomstige navorsers in staat te stel om die werk te herhaal. Laastens is objektiwiteit verseker deur die stappe wat geneem is om te verseker dat die data en die resultate dié van die deelnemers sou wees en nie dié van die outeurs nie.

\section{Resultate en bespreking}

'n Ryke oes van data is vanaf die deelnemers verkry. Die meeste deelnemers het gemaklik tydens die onderhoude voorgekom; sommige deelnemers het baie spesifiek gereageer terwyl ander se antwoorde vaag, huiwerig en meer in die algemeen was.

Die verkreë temas word vervolgens binne die vier gestelde doelstellings vir die navorsing aangebied (vgl. 'Doel' hierbo).

\section{Die verhouding waarbinne seksuele intimiteit geniet en uitgeleef mag word}

Ses temas het hier na vore gekom.

\section{Tema 1: Kommunikasie}

Agt deelnemers het aangedui dat kommunikasie belangrik is.

Twee subtemas, naamlik eerlikheid en komplimentering, het in die tema van kommunikasie na vore gekom. Die egpare voel dat hulle alle behoeftes, kwellings en menings eerlik met mekaar moet kan bespreek. Twee deelnemers het dit soos volg verwoord:

'Eerlikheid met mekaar is dat as iets nie goed verloop nie of as een van ons ongemaklik voel met die situasie om dan dit te sê, en die vertroue dan dat jy weet dat die ander persoon regtig daarna luister en dit ter harte neem'.

En:

'Die belangrikste aspek van die huwelik vir die seksuele uitlewing is dat ' $n$ mens eerlik moet kan wees met mekaar en dit gaan daaroor om al jou verwagtinge en behoeftes aan jou maat te kan bekend maak, en om soveel as moontlik te probeer dat hy ook gemaklik voel om sy behoeftes aan jou bekend te maak, sonder om iets weg te steek'.

Die vier vrouedeelnemers ervaar die verbale komplimentering en 'n gebaar van waardering van hulle eggenote belangrik vir die opbou en instandhouding van die huweliksverhouding. Sommige van hulle stel dit soos volg: 'Julle moet mekaar waardeer, komplimenteer en mooi goed vir mekaar sê.'; 'n Ander sê: 'Nie net tydens foreplay [die voorspel] nie. As jou man vir jou mooi goed gaan sê tydens seks, gaan dit ook vir jou lekker wees om dit te doen.'

\section{Tema 2: Gemaklikheid}

Meer as die helfte van die deelnemers het aangedui dat dit belangrik is om met jouself en met jou huweliksmaat gemaklik te wees. Die subtema, om gemaklik te wees met jouself, het na vore gekom in verskeie deelnemers se antwoorde. Twee deelnemers stel dit soos volg:

'... [om] confident [gemaklik] in hulself en in hulle eie vel [te] wees, ... beteken jy moet kan kaal wees sonder om te voel dat jy agter ' $n$ $\mathrm{n}$ handdoek moet probeer wegkruip die heeltyd'.

Of ook 'As mens nie gemaklik voel met wie jy is nie, gaan jy nie gemaklik kan voel met iemand anders nie. Veral nie in die slaapkamer nie.'

Veral onder die vroulike deelnemers blyk die tema, om gemaklik in die teenwoordigheid van die eggenoot te kan wees, baie belangrik. Die deelnemers verduidelik dit soos volg:

" $n$ Baie belangrike aspek vir die genieting van seksuele verkeer is dat elke party ten volle op sy/haar gemak moet voel by die lewensmaat en dat hulle mekaar sal aanmoedig om te ontspan'.

Ook: 'Gemaklik is maar net gemaklik, om nie te hoef weg te kruip as jy kaal is nie.'

Die wete dat die egpaar se seksuele intimiteit nie met ander bespreek word nie, is vir een deelnemer ' $n$ belangrike voorvereiste vir hierdie gemaklikheid. Sy stel dit soos volg:

'... daarom voel ek gemaklik by hom, want ek weet niemand sal ooit daarvan weet nie en ek weet dit sal altyd net 'n privaat grappie wees tussen my en hom'.

\section{Tema 3: Liefde}

Vyf deelnemers het aangedui dat liefde 'n belangrike kenmerk van die verhouding moet wees waarbinne seksuele intimiteit geniet en uitgeleef mag word. Die liefde word 
deur verskillende deelnemers verskillend getipeer: 'Mens (moet) kan sien dat hulle mekaar liefhet, mekaar liefiediefie.'; 'Opwindende liefde [is] moeilik om te behou in die huwelik.' en 'Ek voel dat die belangrikste vir die vrou liefde is, emosioneel en fisies.'

Die subtema van ' $n$ begeerte na mekaar is ook deur twee deelnemers vermeld as ' $n$ kenmerk van hierdie seksueel intieme verhouding:

'... daardie twinkle [vonkel] in 'n getroude man se oë as hy jou kaal sien. Dit sê vir jou dat jy die enigste vrou is in sy oё, die enigste een waarna hy op hierdie manier kyk'.

En ook: '... aangetrokke voel teenoor my vrou en sy moet aangetrokke voel oor my om die seksuele aspek vol te verryk'.

\section{Tema 4: Vertroue}

Twee subtemas is by vertroue ingesluit, naamlik vertroue dat die huweliksmaat nie sal uitpraat oor die intieme verhouding nie (vier deelnemers) en vertroue in die algemeen. Oor eersgenoemde het 'n deelnemer gesê:

'As ek nie my man vertrou het nie, sou ek nooit gemaklik gewees het nie. Omdat ek hom vertrou en omdat ek die konfidensialiteit van ons slaapkamer vertroulik hanteer, en respek het daarvoor'.

Soos vroeër vermel is, het ' $n$ ander deelnemer gemeld: '... daarom voel ek gemaklik by hom, want ek weet niemand sal ooit daarvan weet nie ...'

Die subtema van algemene vertroue staan vir drie deelnemers sentraal in die sukses van hulle huwelike. Dit beteken dat hulle hulle maat moet kan vertrou in alle fasette van hulle huwelik. 'Dit is regtig die heel belangrikste dat alles uit vertroue uitvloei, as jy iemand 100 persent kan vertrou, kan ek nie dink dat daar 'n probleem kan wees nie ...'; en 'Die belangrikste ding is om jou maat of jou huweliksmaat te vertrou met jou hele liggaam, en weet dat jy die enigste een is in sy lewe, sy kop, sy bed en alles.'

\section{Tema 5: Respek}

Vier deelnemers was van mening dat respek, veral wedersydse respek, belangrik is vir die intimiteit binne die huwelik. Sommige van hulle opmerkings was die volgende:

'Respek is baie belangrik. Die wete dat jou maat jou respekteer en onvoorwaardelik liefhet, net soos jy is. Dit bring vertroue mee dat jou maat die beste vir jou wil hê'.

En:

'Mens moet weet hoe om jou huweliksmaat te hanteer, en dat jy moet weet waarvan sy hou en waarvan sy nie hou nie. En as sy nie van iets hou nie, dan moet jy dit respekteer'.

En ook:

'Vir die man is die belangrikste respek, hy het nodig om geëerd te voel en verhewe te word bo alle ander, die vrou is die kroon van die man en hy is die koning'.

\section{Tema 6: Opofferings}

Drie deelnemers het melding gemaak van die belangrikheid daarvan om in die huwelik opofferend te wees en dat die huweliksmaats moeite vir en met mekaar moet doen: 'Mens moet soms toegee aan die ander se behoeftes al voel jy nie lus nie, dit doen soms meer goed vir die ander persoon as kwaad vir jou.' En 'Dit is belangrik om te gee en die huwelikslewe vir mekaar lekker te maak.'

\section{Die man en vrou se plig teenoor mekaar rakende die seksuele}

Drie temas kom hier na vore, elkeen met 'n aantal subtemas.

\section{Tema 1: Seks as verpligting of opdrag in die huwelik}

Tien deelnemers het aangedui dat seks 'n huweliksplig is wat huweliksmaats teenoor mekaar het. Twee het dit soos volg verduidelik: 'Seks is verseker 'n verpligting en 'n opdrag.' En: 'Ja, dit is ons opdrag.' Slegs een deelnemer het gevoel dat dit nie ' $n$ verpligting of opdrag binne die huwelik is nie. Hy verwoord dit soos volg: '

'Nee, nie'n opdrag nie. Daar kan nie 'n huwelik sonder seks wees nie. As dit vir my maat ' $n$ verpligting of voorwaarde is om met my seks te hê of as my maat dit sien as 'n verpligting teenoor my sou ek definitief my huwelik sterk onder oë neem - vir my moet dit 'n wilfaktor hê, nie 'n verpligtingsfaktor of opdragfaktor nie'.

Die verduideliking wat die deelnemers gee waarom hulle meen dat dit 'n plig en 'n opdrag is, kan in twee subtemas verdeel word, naamlik dat dit ' $n$ bybelse voorskrif is en dus God se wil, maar ook dat dit voordelig vir die huwelik is. Sewe van die deelnemers het aangedui dat seks in die huwelik bybelse voorskrifte en God se wil is. Sommige van die deelnemers het dit soos volg gestel:

'In die Woord, in 1 Korintiërs 7:3, staan dit so dat dit 'n opdrag is en dat as jy getroud is die man en die vrou se liggame aan mekaar behoort en dat mens nie mekaar daarvan mag weerhou nie, behalwe vir kort tye en dan moet mens weer bymekaar kom'.

Ook:

'Hy het die opdrag gegee omdat Hy weet dat dit'n mooi, heilige, liefdevolle gebaar is tussen man en vrou, in die huwelik. Hy het geweet dat dit die huweliksverhouding sal versterk'.

En: 'Want Hy het vir Adam en Eva gesê dat ons die aarde moet bewoon en vermeerder ... In die Bybel, in Hooglied, word daar van hierdie mooi liefde gepraat.' Een van die vier deelnemers wat seks as voordelig vir die huwelik beskryf het, het dit soos volg gestel:

'Dit is iets wat beide partye nodig het en is soos die gom in die huwelik. Elke keer as mens seks het, word jy stywer aan mekaar gegom, en as jy nie seks het nie, raak die gom elke week bietjie meer los'.

Nog iemand stel dat ' $[d]$ ie voordele van seks is dat dit mens nader aan mekaar bring'.

\section{Tema 2: Afdwingbaarheid of aanspraak wat die huweliksmaats het op seks in die huwelik}

Ses van die deelnemers was dit eens dat 'n mens daarop mag aanspraak maak, maar hulle het ook meestal saamgestem dat dit nie afdwingbaar is nie. Party van hulle het dit soos volg verwoord: "n Mens wil dit nie afdwing nie, want seks is nie die tipe ding waar mens iemand forseer om seks te hê nie. Maar mens gaan aanspraak daarop maak.' Ook: 'Ja, 'n man/ 
vrou behoort daarop aanspraak te maak indien hy/sy nie seksuele bevrediging in die huwelik kry nie.'

Vir drie ander deelnemers is enige vorm van dwang onaanvaarbaar. Dit kom na vore in uitsprake soos: 'Hoe kan ek respek hê vir my vrou as ek dit afdwing?' en 'Ek dink nie dit sal voordelig wees vir 'n verhouding nie en ek kan my nie indink dat enigiemand iets geniet wat nie van albei kante kom nie.'

\section{Tema 3: Eienskappe van 'n gesonde seksuele verhouding}

Die deelnemers het breedvoerig op die vraag rakende die eienskappe van 'n gesonde seksuele verhouding geantwoord en tien subtemas is uit hierdie data verkry.

\section{Subtema 1: Behoeftebevrediging}

Sewe deelnemers het genoem dat die bevrediging van seksuele behoeftes sentraal in die huwelik is. Sommige van hulle het dit soos volg verwoord: "n Eienskap is dat'n gesonde seksuele verhouding een is waar albei bevredig word, want obviously [vanselfsprekend], as een dit nie geniet nie, is dit tog nie suksesvol nie.'; en 'Voldoen gereeld in mekaar se behoefte.' Ook 'Om in die ander persoon se behoeftes te voorsien, dit maak nie saak hoe jy daarin voorsien nie. Jou opdrag is om dit te doen.'

Ten einde hierdie behoefte te kan bevredig, blyk:

'... dat mens mekaar se behoeftes ken en moet in dit voldoen, of bevredig. ' $n$ Man is 'n sportsmotor en ' $n$ vrou 'n stoomtrein. Want ' $n$ man kan dadelik aangesit word en is dadelik reg vir die ding, en ' $n$ vrou is meer soos ' $n$ stoomtrein, ' $n$ vrou moet eers warm gemaak word'.

En:

'Maak seker dat albei partye elke keer 'n klimaks bereik, want in daardie geval maak die res van die daad nie meer saak nie. Dis belangrik, want as ek my vrou bevredig, gaan sy nie op 'n ander plek soek daarvoor nie'.

\section{Subtema 2: Seksuele omgang moet gereeld plaasvind en} daarom moet daarvoor tyd gemaak word

Hierdie tema het in sewe deelnemers se antwoorde na vore gekom. Party van hulle stel dit soos volg:

'As jy vir lank nie seks het nie en jouself weerhou ... jy voel jy het dit nie meer nodig nie. Maar as jy gereeld daaraan blootgestel word, dan is die memory [herinnering] daarvan vars, en ... as dit op 'n gereelde interval is, beteken dit ook baie vir die emosionele verbintenis tussen jou en jou man'.

En:

'Dit is soos om 'n atleet te wees: Of jy nou lus is om te gaan oefen of nie, jy gaan oefen, en hoe meer jy gaan oefen, hoe fikser gaan jy word. En ek dink dis nogal dieselfde met seksuele intimiteit, of met intimiteit: Hoe meer gereeld mens seksueel intiem verkeer, hoe 'seks'-fikser raak jy en hoe meer gaan jy dit wil doen met mekaar'

Die rede waarom tyd gemaak moet word vir seks, is volgens sommige deelnemers toe te skryf aan die gejaagde tye waarin ons lewe.
'Mens moet vir seker tyd inruim en sorg dat jy nie in jou week te besig is nie. Jy het dit nodig, jou man het dit nodig en julle huwelik het dit nodig'.

Ook:

'Mens moet, omdat ons lewens so gejaag is, letterlik vir mekaar tyd maak, of 'n afspraak maak om seks te hê soms. Want dan weet jy wat lê voor vir jou die naweek, mens reël dan nie ander goed vir daardie tyd nie, en mens voel dan nie deur die week skuldig as daar dae sonder seks verbygaan nie'.

\section{Subtema 3: Eerlike kommunikasie}

Volgens ses deelnemers moet die huweliksmaats eerlik oor alle algemene verhoudingsake kommunikeer, maar ook spesifiek oor sensitiewe sake rakende seks. Party deelnemers het dit gestel dat:

'As ons kan kommunikeer en gemaklik is met mekaar en die vrymoedigheid het om vir my vrou te sê: Ek hou daarvan, doen dit meer, of as sy vir my sê ek hou hiervan doen dit meer, dan gaan dit verseker dat albei bevredig word'.

Ook:

'Partykeer is dit goed om jou behoeftes te verbaliseer. As jy nie lus is vir seks nie vir 'n lang ruk is dit nie te sê dat jou huweliksmaat dieselfde voel nie, en as hy nie na jou toe kom en vir jou vra nie kan mens dit afskuif en naderhand kan dit ontwikkel in 'n probleem'.

'n Ander deelnemer het gemeen ' $[a]$ s jy nou seks met jou vrou wil hê, dan moet jy openlik met haar daaroor kan gesels'.

\section{Subtema 4: Liefde en die begeerte na mekaar}

Liefde en 'n begeerte na mekaar is nou verweef binne die huwelik. Vir vyf deelnemers is liefde in die gesonde seksuele verhouding binne die huwelik belangrik. 'Seks sonder liefde is verkeerd, om net seks te hê, om seks se onthalwe, is 'n ongesonde ding' en 'Solank beide dit wil doen, gemaklik is om te doen wat hulle wil en alles in liefde doen - is dit ' $n$ gesonde seksuele verhouding.'

Vir sommige deelnemers is begeerte belangrik. 'Om nog die vuur by mekaar wakker te maak, dit laat 'n mens weer voel soos toe jy verlief was'; 'As ek partykeer na hom kyk, dan is hy net vir my nog verskriklik mooi en wil nou net daar by hom wees ...' en 'Julle beide weet dat julle deur die ander een eerste gestel word, liefgehê word en begeer word.'

\section{Subtema 5: Onselfsugtigheid en die bereidheid op opofferings te maak}

Volgens vyf deelnemers is onselfsugtigheid en die bereidheid om opofferings te maak ' $n$ bewonderingswaardige eienskap. Hulle verduidelik dit soos volg: 'Om nie selfsugtig te wees nie en dus te verseker dat albei partye dit geniet.'; 'Dis nie regverdig dat die man altyd die een is wat dit moet inisieer nie, meeste vrouens het nie 'n seksdrif soos 'n man nie. Man voel dalk half dat hy altyd daarvoor moet vra of pleit, en dit is nie regverdig nie.'; en 'partykeer moet jy compromise['n tussenoplossing vind].

\section{Subtema 6: Humor}

Hierdie tema is deur vier deelnemers genoem wat dit soos volg verwoord: 'Dis baie belangrik om nie te ernstig te wees 
nie, mens moet kan lag oor goed'; en '[s]eks hoef nie altyd ernstig te wees nie, 'n mens kan net ontspan en jou geniet'.

\section{Subtema 7: Respek}

Respek was vir drie van die deelnemers 'n belangrike faktor in die bepaling van die gesondheid van 'n egpaar se seksuele verhouding. Twee van hulle sê die volgende: 'Respek gaan daaroor dat jou man nie van jou dinge kan verwag waarmee jy ongemaklik is nie, want dan is dit liefdeloos.' Ook die volgende:

'As my vrou respek het vir my en weet ek is 'n aandmens, sou sy dit respekteer en my wil bevredig op tye wat my pas, en net so, ek weet my vrou is 'n oggendmens, net so sal ek dit respekteer en vir haar gee wat sy wil hê'.

Benewens bogenoemde sewe subtemas het drie verdere subtemas na vore gekom, maar is slegs deur een of twee deelnemers genoem.

Tot die outeurs se verbasing het slegs twee deelnemers enigsins na God of spiritualiteit verwys toe hulle oor die eienskappe van die gesonde seksuele huweliksverhoudinging gepraat het. Een deelnemer het dit soos volg verduidelik:

'Elke keer is dit 'n heilige daad voor God en mens moet dit in daardie lig sien. Dit sal jou vrywaar van disrespek, as jy vir jouself sê: Dis die eenwording voor God hierdie, dit is nie speletjies nie'.

'n Verdere verrassende aspek is die afwesigheid van die term intimiteit in talle van die deelnemers se antwoorde. Een van die twee deelnemers wat wel daarna verwys het, het dit soos volg verwoord:

'Ek wil graag hê my man moet eers my lyf bekyk, ek wil die begeerte in sy oë sien, ek wil hê hy moet kan rustig en intiem wees saam met my, voor seks, anders beteken dit vir my niks. Vir my en my man is die intiemste om saam in die bad te sit en wyn drink. Om saam in die kerk te sit, en hande vas te hou, dit is intimiteit'.

Een deelnemer voel dat die saamdoen van nuwe dinge iets is wat die seksuele verhouding kan bevorder:

'Dis belangrik om saam nuwe goed te sien en ondek, bv. om te reis of om saam iets nuuts te leer - dus nie boring [vervelige] goed die heeltyd te doen nie, byvoorbeeld elke naweek te braai by jou huis nie, of om by dieselfde restaurant te gaan eet nie. Daar moet 'n lus vir die lewe wees en ook 'n lus om saam met jou partner [lewensmaat] te wees'.

\section{Die vryheid en misterie wat seksuele intimiteit binne die huwelik inhou}

Die inligting oor hierdie afdeling word in twee dele aangebied, naamlik die vryheid en die grense van seksuele intimiteit in die huwelik en die besondere bydrae wat die seksuele komponent tot die egpaar se huweliksverhouding lewer.

\section{Die vryheid en die grense van seksuele intimiteit in die huwelik}

Vyf temas is uit hierdie data verkry.

\section{Tema 1: Alles is geoorloof indien albei partye gemaklik is}

Nege deelnemers is van mening dat die vryheid en die beperkings aangaande seksuele intimiteit en eksperimentering hoofsaaklik bepaal word deur die gemaklikheid wat albei huwelikmaats daarmee het. Sommige van hulle verwoord dit soos volg: 'Alles wat vir my en my man gemaklik is, is aanvaarbaar. Daar is nie regtig perke nie. As dit net jy en jou man is, kan dit regtig nie sondig wees nie.'; 'Eksperimentering is aanvaarbaar, solank albei partye deurentyd gerespekteer voel en gemaklik voel met die dinge waarmee daar geëksperimenteer word.'; en 'Dit wat in die slaapkamer mag gebeur, is byna grensloos, mits albei hou van wat gebeur, nie fisies of emosioneel skade ly nie, en nie verneder voel nie.'

\section{Tema 2: Eksperimentering}

Sewe deelnemers het eksperimentering in 'n positiewe lig beskou, drie het aangedui dat dit onnodig is terwyl niemand gedink het dat seksuele eksperimentering in die huwelik ongeoorloof is nie.

Twee van die deelnemers wat eksperimentering as onnodig beskou, het dit soos volg verduidelik: 'Ons eksperimenteer nie vreeslik nie, want dit is nie in my persoonlikheid regtig nie.'; 'Dit kan goed wees, maar dit is nie altyd nodig nie. Mens het nie sulke goed nodig nie.'

Drie subtemas het ten opsigte van seksuele eksperimentering na vore gekom.

\section{Subtema 1: Eksperimentering hou voordele in}

Sewe deelnemers het seksuele eksperimentering in 'n positiewe lig beskou. Hulle het die volgende hieroor genoem:

'Eksperimentering is geoorloof omdat dit die wyse is waarop 'n man en vrou mekaar se behoeftes leer ken en verstaan sodat hulle altyd aan mekaar se behoeftes kan voldoen. Hierdie behoeftes kan ook verander van tyd tot tyd; daarom is gereelde eksperimentering baie belangrik'.

Daar is ook gestel dat'... met allerhande sex toys [seksspeelgoed] in die slaapkamer ... as dit hulle help, en as dit goed is vir hulle seksuele verhouding en intimiteit'; en '[ $n$ ]atuurlik sal mens mekaar op ander wyses bevredig wat nie koïtus is nie. Mens moet eksperimenteer met hierdie tipe goed.'

\section{Subtema 2: Alles binne God se wil, is aanvaarbaar}

Ses deelnemers het verwys na God se wil aangaande die vryheid van seksuele eksperimentering in die breë. Min deelnemers kon hulle standpunte staaf deur na spesifieke verse of tekste in die Bybel te verwys. Sommige van die deelnemers sê die volgende in hierdie verband: 'As jy dit kan meet aan die liefdevolle huweliksverhouding wat die Here daar gestel het, is dit geoorloof.'; 'Eksperimentering is toelaatbaar, solank dit nie buite die Christelike raamwerk beweeg nie. God [het] ons vir mekaar gegee om mekaar ten volle te geniet.'; en 'Wat ook al die egpaar oor saamstem en solank dit nie ingaan teen die Woord van God nie.'

Vier deelnemers het in meer besonderhede verduidelik wat God se wil is, naamlik dat seks veronderstel is om in liefde en binne die huwelik plaas te vind. Twee deelnemers het dit soos volg gestel: 'Dit moet in liefde wees, nie in woede nie. 
Wanneer jy en jou man byvoorbeeld baklei het of as 'n man sy vrou daarmee wil seermaak of verneder, in plaas daarvan dat dit 'n manier is om julle liefde vir mekaar te wys.'; 'Alles is aanvaarbaar, solank dit in die huwelik gebeur.'

\section{Subtema 3: Wyse van eksperimentering}

Tot die verbasing van die eerste outeur was vier van die deelnemers gewillig, selfs gretig, om oor anale seks en die aanvaarbaarheid daarvan in die huweliksverhouding te praat. Twee deelnemers was van mening dat dit aanvaarbaar is, en twee het gemeen dat dit onaanvaarbaar is.

Voorstanders van anale seks het dit soos volg beskryf:

'Ek glo nie dat anale seks sodomie is nie ... dit is 'n sonde vir twee mans om met mekaar seks te hê. Maar'n man en 'n vrou kan met mekaar seks hê op enige manier. As dit vir 'n man en 'n vrou genotvol is en albei is happy [gelukkig] daarmee, dan sien ek nie hoe ek iemand kan veroordeel wat dit doen nie'.

En ook: 'Ja [vir anale seks], want alles binne die huwelik is aanvaarbaar.' Die ander twee deelnemers het hulle standpunt teen anale seks soos volg verduidelik:

'Anale seks is onaanvaarbaar, siende dat dit onnatuurlike omgang is en dat dit nie aanvaarbaar is in die oë van die Here nie. Daar word duidelik daaroor gepraat in Romeine 1. God keur dit nie goed nie. Dit is 'n bespotting van iets wat God geskape het om goed en heilig en mooi te wees'.

Ook: '[Indien] dit binne die gesonde boundaries [grense] van die Woord van God geskied dat dit nie anaal van aard is nie.'

Ses van die deelnemers het vryuit gesels oor hulle houdings ten opsigte van seksspeelgoed. Vier deelnemers was van mening dat seksspeelgoed aanvaarbaar is in die seksuele eksperimentering van ' $n$ egpaar. Sommige van hulle meld onder andere: 'Seksspeelgoed is vir my aanvaarbaar, want mens het partykeer behoefte aan bietjie eksperimentering, mens moet bietjie eksperimenteer en kinky [pervers] wees.'; 'In verband met sex toys [seksspeelgoed] is dit aanvaarbaar en wat mens daarmee maak, is aanvaarbaar solank albei persone daarmee gemaklik is.' en 'Allerhande sex toys [seksspeelgoed] in die slaapkamer ... as iemand mank loop en hy het regtig 'n kruk nodig om te kan lekker loop, dieselfde kan geld vir hierdie tipe goed.' Twee ander deelnemers wat seksspeelgoed onaanvaarbaar vind, verwoord hulle oortuiging soos volg: 'Met speelgoed of foto's dink ek seks word pervers en dit is heilig.'; 'Enige ding wat vir ons onnatuurlik is wat jy in jouself indruk is onaanvaarbaar, want dit is onnatuurlik, en God het dit nie daarvoor gemaak nie.'

Eksperimentering met rolspel, wat sou beteken dat een of albei huweliksmaats soos iemand in 'n spesifiek beroep aantrek en dan binne hierdie rolle mekaar seksueel opwek ten einde die seks meer opwindend te maak, is deur twee deelnemers bespreek. Albei het hierdie tipe eksperimentering as positief beskou: 'Opwindende seksspeletjies [soos rolspel en bordspeletjies] is aanvaarbaar' en 'sexy onderklere of ... vreemde pakkies aantrek, dis oulik'.

Ses deelnemers het aangedui dat eksperimentering met verskillende seksposisies geoorloof is: 'Ja, om nie altyd in dieselfde posisie te wees nie, gee mens elke keer 'n ander view [uitsig], en dit is opwindend.'; 'Eksperimentering met verskillende posisies is aanvaarbaar.'; en 'Mens kry dalk skaam [tydens sommige van die posisies], maar dit is opwindend en mens kan lekker vir mekaar lag soms.'

\section{Tema 3: Geen derde party is geoorloof nie}

Vyf deelnemers beklemtoon die feit dat 'n derde persoon nie ingesluit mag word in die seksuele intimiteit van die huwelik nie. Voorbeelde van hierdie opmerkings sluit in: "n Derde party is nie reg nie, want die huwelik is tussen twee mense, 'n man en 'n vrou, en God as die enigste derde party saam met daardie persone in die huwelik.'; 'Daar mag nooit 'n derde persoon betrokke wees nie, nie fisies nie, en ook nie in die gedagtes van een van die huweliksmaats nie.'; en 'Dit is verder onaanvaarbaar om meer as een seksmaat terselfdertyd te hê, siende dat die eenwording van twee persone op hierdie wyse onteer word.'

Geen deelnemers het aangedui dat dit aanvaarbaar is dat ' $n$ derde persoon in die seksuele verhouding van die egpaar toegelaat word nie.

\section{Tema 4: Geen pornografie is geoorloof in die huwelik nie}

Vyf deelnemers het aangedui dat die gebruik van pornografie tydens seksuele intimiteit totaal ontoelaatbaar is. Sommige van die opmerkings hieroor was: 'Pornografie as aanmoediging vir ereksie is onaanvaarbaar, siende dat dit abnormale idees skep en dat dit dieselfde is as om iemand anders in die geslotenheid van die huwelik in te nooi.'; 'Pornografie is in elk geval belaglik, dit is glad nie realisties nie. Dit skep abnormale verwagtinge waarby 'n normale persoon nooit gaan bykom nie.'; en 'Dit is nie wat God dit bedoel het om te wees nie.'

Ook hier, net soos by die vorige vraag, het geen deelnemers aangedui dat hulle anders oor die aspek voel nie.

\section{Tema 5: Seksuele intimiteit moet geniet word}

Vier deelnemers het gemeld dat seksuele intimiteit, en daarom ook die eksperimentering wat daarmee gepaard gaan, deur albei partye geniet moet word. Twee van hulle het dit soos volg verwoord: 'Albei moet hulleself geniet, dit is ontsaglik belangrik, want ons is vir mekaar gegee deur God, ons is letterlik soos 'n legkaart wat bymekaar pas.'; en 'As mens na Hooglied byvoorbeeld kyk, kan jy duidelik sien dat dit eroties was ... Mens kon hoor die mense in die boek was regtig seksueel opgewek en opgewerk.'

\section{Die besondere bydrae wat die seksuele komponent van die egpaar se huwelik tot hulle huweliks verhouding lewer}

Deelnemers het breedvoerig geantwoord oor die bydrae van hulle seksuele verhouding tot hulle huwelik. Drie temas is hieroor geïdentifiseer. 
Tema 1: Die seksuele komponent van ons huwelik bring ons nader aan mekaar

Byna al die deelnemers (nege) het genoem dat die seksuele komponent van hulle huwelik hulle nader aan mekaar bring en hulle verhouding laat groei. Die deelnemers het by hierdie vraag mooi metafore en uitdrukkings gebruik om hulself uit te druk. Dit was duidelik dat die deelnemers baie sterk oor hierdie saak voel. Sommige van die uitsprake was die volgende: 'Seks is soos hoendersop vir die huwelik. Dit maak dit gesond, dit laat 'n mens nader aan mekaar groei.'; 'Dit is die gom vir die huwelik. Dit is die plek waar mens recharge [herlaai] in jou huwelik. Dit is die gom wat die man en die vrou bymekaar hou en nader aan mekaar bring, en hou ... julle verstaan mekaar beter en julle begryp meer van mekaar'; en 'Dit bring die balans en harmonie terug en dit bring vrede, geluk en rustigheid. Dit is 'n stukkie hemel op aarde en ' $n$ metafisiese konneksie wat 'n kringloop voltooi.'

Twee subtemas kon binne hierdie tema onderskei word, naamlik dat die seksuele verhouding liefde en intimiteit kweek en dat dit vertroue tussen die huweliksmaats bevorder.

\section{Subtema 1: Kweek liefde en intimiteit}

Teen die outeurs se verwagting in het slegs drie deelnemers spesifiek aangedui dat hulle seksuele verhouding 'n dieper liefde vir mekaar kweek:

'Dit maak my net soveel liewer vir haar daarna, mens voel so naby aan mekaar, dit is die naaste wat mens aan mekaar kom, mens wil mekaar net drukkies gee en soentjies gee. Dis awesome [fantasties]. Daar is nie woorde wat dit kan beskryf nie'.

Die volgende is ook genoem: 'Dit is lekker, dit laat 'n mens weer bietjie verlief ook voel.'; en 'Seks bind ons saam, bevestig ons liefde.' Slegs een deelnemer het spesifiek gemeld dat hulle seksuele intimiteit bevorder word: 'Dit bring intimiteit tussen ons en die eenwording van ons vlees bring fisiese eenheid.'

\section{Subtema 2: Bevorder vertroue}

Een deelnemer het genoem dat die seksuele komponent van die huwelik vertroue tussen die huweliksmaats bevorder. Hy het dit so verwoord: 'Dit laat my voel dat ek haar vertroue 100 persent het. Dit is ' $n$ unieke, emosionele verbintenis. Dit is seksueel, maar meer emosioneel. Dit is belangrik en dis amazing [ongelooflik] en spesiaal.'

Tema 2: Die sukses van die seksuele verhouding beïnvloed die sukses van 'n huweliksverhouding in 'n baie groot mate en omgekeerd

Agt deelnemers het aangedui dat 'n suksesvolle huweliksverhouding en 'n suksesvolle seksuele verhouding regstreeks met mekaar verband hou en mekaar deurentyd beïnvloed. Enkele van die uitsprake was: 'Wanneer'n paartjie seksuele probleme ondervind in 'n verhouding, maak dit 99 persent van die verhouding suur.'; "n Man en vrou wat seksueel gelukkig is, is minder geneig om te verneuk en is meer geneig om positief te wees in die geselskap van sy/haar seksmaat.'; 'As jy probleme het met seks, is dit die eerste plek waar 'n huwelik se probleme begin. Dit plaas stremming op die ander fasette van jou huwelik en vice versa.'; en 'Maar as daar ' $n$ goeie sekslewe is, is jy meer op jou gemak by mekaar, die vertroue neem toe, die eerlikheid neem toe, die opregtheid van die verhouding neem toe, die sekuriteit van julle verhouding neem toe.'

Hierdie sterk oortuiging van die verband tussen die sukses van die huweliksverhouding en die sukses van die seksuele verhouding bring mee dat die deelnemers poog om albei te handhaaf en te bevorder.

\section{Tema 3: Goed vir 'n mens se gemoed}

Drie deelnemers het gemeld dat 'n goeie seksuele lewe 'n invloed op die huweliksmaats se gemoed, selfbeeld en stresvlakke kan uitoefen. Hulle stel dit soos volg:

'Dit laat my as vrou goed voel, begeerlik en mooi vir my man, wat weer goed is vir my selfbeeld en dalk 'n invloed kan hê oor hoe ek vir myself en my liggaam sorg'.

Of:

'Dit is nogal vir hom belangrik dat ek mooi lyk en so. Dit is vir my ook belangrik as ek sien jy ... jy weet jy sien sommer in sy oë hy KYK nou vir jou en jy is vir hom mooi en dit is net kosbaar. Dit is baie lekker om so te voel'.

En '... dit is ook 'n goeie uitlaat vir stres.'

Die egpaar se intieme tye hou dus ook fisiese voordele vir die egpaar in en kan die huweliksmaats oor die algemeen beter oor hulleself laat voel.

\section{Die eksklusiwiteit van seksuele intimiteit binne die huwelik}

Uit die resultate blyk dat die huwelik sekere beperkings op die egpaar se verhoudings met ander mense plaas. Drie temas is in hierdie verband geïdentifiseer.

\section{Tema 1: Individuele vriendskappe met ander mense is nie nodig nie}

Vyf deelnemers is van mening dat indien die egpaar se verhouding van so 'n aard is dat hulle mekaar se behoeftes in alle opsigte vervul - ook dié van vriendskap - is die aanknoop van individuele vriendskappe onnodig. Sommige van hulle opmerkings was die volgende:

'Wat soek jy nog by iemand van die teenoorgestelde geslag as jy 'n man het. Dieselfde andersom; my man bel my, hy praat met my. Die naaste wat hy aan vriendinne kom, is vrouens by die werk, en dit is platonies, want hy het ook nie 'n behoefte om dieper dinge met ander vrouens te bespreek nie, want sy vrou bevredig dit alles'.

'n Ander persoon sê:

'... want dit (is) die grootste voorreg om net mekaar nodig te hê. Ek noem my mansvriende nog steeds my mansvriende, maar die vriendskap se dinamiek het heeltemal verander ... my man vul nou al hierdie behoeftes'.

Ook: 'Ek hou nie van met ander vrouens kuier of in hulle geselskap te wees nie, ek het myself oorgegee aan my vrou en sy is vir my genoeg.' 
Drie deelnemers het aangedui dat daar 'n tipe verwydering of mate van afsondering plaasvind as gevolg van die eksklusiwiteit van die egpaar se huwelik en seksuele verhouding. Twee van hulle stel dit soos volg: 'Dit maak ons meer afgesonderd teenoor ander mense, omdat ons nie hulle binne ons space [persoonlike ruimte] laat inkom nie omdat hulle nie seksuele intimiteit met ons deel nie.'; 'Dit het te doen met die feit dat ons getroud is en mekaar se man en vrou is en dat ons huwelik as geheel heilig is.'

\section{Tema 2: Vertroue in mekaar maak beperking as sodanig onnodig}

Drie deelnemers voel dat die mate van vertroue wat die man en die vrou in mekaar stel spesifieke beperkings onnodig maak. Twee beweer: 'Ek vertrou haar ten volle dat sy die regte besluite sal neem. Ek weet dat sy nie in versoekings gelei sal word nie.'; en 'Jy moet jou maat genoeg kan vertrou dat dit vir jou oraait [aanvaarbaar] is as jou man met iemand gaan koffie drink wat jy miskien nie so goed ken nie.'

Drie deelnemers is van mening dat hulle vriendskappe met lede van die teenoorgestelde geslag nie regtig beïnvloed word deur hulle huweliksverhouding nie. Twee deelnemers verwoord hulle persepsies soos volg: 'Ons verhouding beïnvloed nie my interaksie met mans nie.'; en 'Ek dink nie sy sal omgee as ek saam met ander vroumense gaan koffie drink of waar ook al met werksfunkies saam met hulle gaan nie.'

\section{Tema 3: Vriendskappe is binne sekere perke steeds toelaatbaar}

Vier deelnemers meen dat alle behoeftes van die huweliksmaats nie noodwendig in die huwelik bevredig word nie en dat vriendskappe daarom wel moontlik is. Party van hulle verduidelik hulle sienings soos volg: 'In die sin van die seksuele is daar beslis dinge soos eksklusiwiteit, maar in die algemene verhouding met mense van die teenoorgestelde geslag het ek nie 'n probleem nie.'; en 'Ek kan ander mans drukkies gee, met hulle gesels en saam met hulle gaan middagete eet, en my man gee glad nie om nie. Daar is baie dinge wat ons met ander mense deel en saam met ander mense doen.'

Vriendskappe is dus vir sommige egpare steeds in orde, maar soos die volgende subtemas aandui, is daar hieroor spesifieke menings.

\section{Subtema 1: Beperk vriendskappe tot gesamentlike vriende}

Om vriende te hê, is vir twee deelnemers aanvaarbaar, maar dan moet dit liefs beperk word tot mense wat met albei huweliksmaats bevriend is:

'Jy gaan drink nie alleen koffie saam met iemand nie, behalwe as dit ' $n$ baie goeie vriend is - verkieslik'n gemeenskaplike vriend, of iemand met wie jy regtig vriende is, wat vir die ander party aanvaarbaar sal wees'.
En:

'Jy vertrou dalk jou maat, maar die ander persoon, die vriend of vriendin, het dalk ander intensies. Daarom is dit net veiliger om meestal gesamentlike kontak met mense van die teenoorgestelde geslag te hê'.

\section{Subtema 2: Beperk gesprekke wat met ander gevoer word}

Vir vier deelnemers was dit ook belangrik dat gesprekke wat met ander persone gevoer word, binne sekere perke moet wees. Twee deelnemers het in hierdie verband uitsprake gelewer.:

'Ons seksuele verhouding is bietjie soos 'n geheim wat ons twee deel, waarvan niemand anders weet nie. Net ek en hy en die Here weet daarvan, dit is waar die eksklusiwiteit inkom. So ons bespreek dit nooit met iemand anders nie'.

En

'Ongeag of dit regtig goed gaan met ons seksuele verhouding of dalk nie so goed gaan nie, niemand weet daarvan nie. Want as mens weet dat dit wat hier in ons slaapkamer gebeur buite oor gepraat gaan word, dan gaan mens nie bereid wees om te eksperimenteer nie, jy gaan nie bereid wees om goeters en erotiese goed te doen nie, want dit gaan op 'n manier uitkom en jou skaam maak dalk'.

\section{Subtema 3: Flankering en vleiende woorde}

Wanneer flankering en vleitaal onskuldig bedoel is, is dit vir twee deelnemers aanvaarbaar. 'Vlei is een ding, maar om te verlei is ' $n$ ander ding. [Dit hang af van] wat jou bedoeling agter dit is.' En:

'Dit is waar mens die lyn kan trek, jy kan met die persoon gesels en maybe [dalk] bietjie flirt of so, maar niks te persoonliks wat jy nie voor jou vrou ook sal sê of doen nie. Dis net om te vlei, dis al'.

Vir ' $n$ ander deelnemer is enige vorm van flankering totaal buite die kwessie:

'... geen vorm van suggestiewe taal nie, want al is dit nog semionskuldig, is dit waar die probleem begin, dit is die saadjie wat geplant word, en dan groei dit tot ' $n$ groot probleem. Die bottom line [waarop alles neerkom] is, jy moet nie vir 'n ander vrou goed sê wat jy nie voor jou vrou vir haar sal sê nie'.

\section{Subtema 4: Beperking word bepaal deur intuïsie of sesde sintuig}

Laastens word die beperking op die egpaar se vriendskappe met ander persone vir twee deelnemers bepaal deur hulle instink, of sesde sintuig. Een deelnemer het dit soos volg verwoord:

'Ons is nie jaloers nie, mens weet mos waar is die limiet. Jy kan agterkom wanneer dit vreemd raak, en jy bly maar dan weg. Mens moet nie aanleiding gee, soos heeltyd grappietjies maak nie. Dis hoe ek weet wanneer iets verkeerd is of naby is ... as ek daardie gut feeling [intuitiewe aanvoeling] kry wat mens ongemaklik maak'.

Uit hierdie temas blyk dit dat die seksuele komponent van die egpaar se huwelik wel beperkings op die huweliksmaats se kontak met persone van die teenoorgestelde geslag plaas, maar dat hierdie beperkings van egpaar tot egpaar verskil. 


\section{Samevatting van resultate}

\section{Die verhouding waarbinne seksuele intimiteit geniet en uitgeleef mag word}

Die deelnemers se uitsprake was dat die verhouding waarbinne seksuele intimiteit geniet en uitgeleef mag word aan sekere vereistes moet voldoen soos liefde, vertroue, respek en die bereidheid om opofferings te maak. Dit stem ten dele ooreen met die basis- en die metateoretiese perspektiewe, hoewel dit anders verwoord is. Die basisteoretiese perspektiewe maak melding daarvan dat die man en die vrou mekaar moet dien en liefhê, terwyl die metateoretiese modelle aandui dat seksuele intimiteit binne 'n konteks van veiligheid, intimiteit, nabyheid en emosionele versorging moet plaasvind.

\section{Die man en die vrou se plig teenoor mekaar rakende die seksuele}

Die deelnemers se uitsprake dat seks in die huwelik 'n verpligting of 'n opdrag is, maar dat dit nie afgedwing behoort te word nie, stem ooreen met die basisteoretiese perspektiewe. Alhoewel die metateoretiese perspektiewe geen spesifieke uitsprake oor hierdie aspek maak nie, sou 'n dwangmatigheid ten opsigte van die seksuele moeilik by die konteks van veiligheid en emosionele versorging kan inpas soos dit in die vooragaande paragraaf aangedui is.

Deelnemers meen dat ' $n$ seksuele verhouding gesond is wanneer die volgende komponente teenwoordig is: behoeftebevrediging, gereelde seksuele omgang, eerlike kommunikasie, liefde en 'n begeerte na mekaar, onselfsugtigheid en die bereidheid om opofferings te maak, humor en wedersydse respek. Hierdie uitsprake stem ooreen met die bevindings van die metateoretiese studie, naamlik dat daar'n sterk verband tussen 'n gesonde seksuele verhouding en huwelikstevredenheid bestaan; dat die bevrediging van seksuele behoeftes van die uiterste belang is; dat seksuele intimiteit gereeld moet plaasvind; dat kommunikasie en eerlikheid aangaande die seksuele nodig is; en dat suksesvolle egpare aanpasbaar en onselfsugtig moet wees.

\section{Die prag, vryheid en misterie van seksuele intimiteit}

Die deelnemers se sienings dat daar 'n groot mate van vryheid aangaande seks en seksuele eksperimentering in die huwelik moet wees, mits albei partye daarmee gemaklik is en dat dit binne God se wil is, stem grootliks ooreen met die bevindings van die basisteoretiese perspektiewe. Die deelnemers se teenkanting teen die insluiting van ' $n$ derde party in die huwelik en die gebruik van pornografie vir seksuele opwekking, is ook in ooreenstemming met die basisteoretiese aspekte.

Die deelnemers se siening dat hulle seksuele verhouding 'n besondere bydrae in hulle huwelik lewer deurdat dit hulle nader aan mekaar bring, stem ooreen met die basis- en metateoretiese perspektiewe. Eweneens is die deelnemers se uitsprake dat seksuele intimiteit geniet mag word, in ooreenstemming met die basisteoretiese en metateoretiese perspektief.
Uitsprake van die deelnemers dat sowel die man as die vrou inisiatief met seksuele intimiteit kan neem, stem ooreen met die basisteoretiese perspektief waar dit aangedui is dat dit geoorloof is vir die man en die vrou om die inisiatief te neem en die ander een uit te nooi. In die lig daarvan dat die metateoretiese bevindings nie beperkings op seksuele intimiteit plaas nie, kan afgelei word dat teoretici heel waarskynlik ook met die deelnemers se siening daaroor sal saamstem.

Die deelnemers se positiewe uitsprake oor eksperimentering en hulle mening dat dit voordele vir die huwelik kan inhou, strook met die basisteoretiese beginsel dat die man en die vrou mekaar se liefkosings en liefde kan geniet en dat daar geen skaamte behoort te wees nie. Hoewel daar nie by die metateoretiese perspektiewe spesifieke uitsprake oor eksperimentering is nie, sou 'n mens na aanleiding van Humphrey (1983:71) se uitsprake oor die belang en eiesoortigheid van die seksuele verhouding kon aflei dat eksperimentering vir die teoretikus ook belangrik sal wees.

\section{Die eksklusiwiteit van seksuele intimiteit binne die huwelik}

Die deelnemers se uitsprake dat vriendskappe met ander persone van die teenoorgestelde geslag binne sekere grense moet geskied, strook met die basisteoretiese perspektiewe wat aandui dat seksuele intimiteit uitsluitlik vir die huweliksmaats bedoel is. Sommige metateoretiese modelle het ook aangetoon dat daar grense rondom die huweliksmaats se verhouding moet wees. Dit is ook aangetoon dat die meeste mense ' $n$ huweliksverhouding ingaan met die verwagting dat seksuele intimiteit vir sowel die man as die vrou eksklusief sal wees tot hulle huwelik. Die oortuiging bestaan dat getrouheid ' $n$ belangrike voorvereiste vir 'n goeie huwelik is.

\section{Gevolgtrekkings en aanbevelings}

Die Skrif gee duidelike riglyne oor talle aspekte van seksuele intimiteit, behalwe oor die omvang van geoorloofde eksperimentering. Die Skrif is nie spesifiek oor die grense van seksuele eksperimentering, byvoorbeeld die gebruik van seksspeelgoed en die beoefening van anale seks binne die huwelik nie. Riglyne hieroor kan wel skriftuurlik afgelei word.

Die naasliggende wetenskappe, Psigologie en Sosiologie, lewer sinvolle insigte ten opsigte van seksuele intimiteit. Die Psigologie lewer relevante insigte oor die seksuele aard van die mens en die belangrikheid van seksuele intimiteit en bevrediging in die huweliksverhouding. Die Sosiologie verskaf inligting met betrekking tot die rol van die huwelik in die samelewing. Hierdie wetenskappe bevat egter ook uitsprake wat teenstrydig met die Skrif is ten opsigte van die beperking van seksuele intimiteit tot die huwelik.

Nuttige vrae rakende seksuele intimiteit is opgestel op grond van die basis- en metateoretiese perspektiewe. Gewillige deelnemers is vir die studie gevind en hierdie deelnemers 
het 'n ryk inligtingsvonds voorsien en die navorsers verras met hulle openlikheid en eerlikheid aangaande hierdie persoonlike saak in hulle lewens. Die navorsers meen dat die empiriese data breedvoerig gerapporteer is en dat 'n besondere bydrae tot die vakgebied van die Praktiese Teologie gelewer is.

Sekere beperkings moet in ag geneem word tydens die interpretasie van die resultate. Die deelnemers was'n beperkte aantal gelowige, jonggetroude egpare van Potchefstroom. Die studie kan dus nie noodwendig van toepassing gemaak word op gelowige egpare in die algemeen nie. Ander aspekte wat ' $n$ beperking op die studie kan plaas, is die feit dat al die deelnemers blank en hoofsaaklik Afrikaanssprekend was. Indien ander persone of etniese groepe by die studie betrek is, sou ander persepsies en houdings moontlik na vore gekom het. Toekomstige studie oor hierdie onderwerp behoort bogenoemde in ag te neem.

Die volgende aanbevelings word gemaak vir die praktykbeoefening en verdere navorsing:

- Pastorale riglyne kan opgestel word vir gebruik tydens beradingsessies en/of verrykingsprogramme vir jonggetroude egpare.

- Pastorale riglyne kan opgestel word vir ouers ten opsigte van die kweek van skrifgefundeerde persepsies en houdings by hulle kinders aangaande seksuele intimiteit en God se wil daarvoor.

- 'n Brosjure waarin pastorale riglyne vir seksuele intimiteit aangedui word, kan opgestel en tydens kategetiese onderrig, kleingroepbesprekings of kampe indringend en biddend hanteer word. Sodanige brosjures kan, met die nodige toestemming, aan ouer kinders by kerke en skole uitgedeel word.

- Navorsingsprojekte kan onderneem word waarin die impak van bogenoemde praktykinsette geëvalueer word.

- Soortgelyke navorsing kan onderneem word met gelowige, jonggetroude persone van ander etniese of taalgroepe, asook met ongelowige, jonggetroude persone.

- Soortgelyke navorsing kan onderneem word metgelowige en nie-gelowige persone van ander ouderdomsgroepe om vas te stel watter ooreenkomste en verskille daar moontlik tussen die verskillende groepe bestaan.

- 'n Vraelys kan ontwikkel word om persone van verskillende ouderdomme se persepsies en houdings oor seksuele intimiteit in die huwelik vas te stel. Hierdeur kan groot groepe deelnemers by kwantitatiewe navorsing betrek word.

\section{Erkenning \\ Mededingende belange}

Die outeurs verklaar dat hulle geen finansiële of persoonlike verbintenis het met enige party wat hulle nadelig kon beïnvloed in die skryf van hierdie artikel nie.

\section{Outeurs bydrae}

Al die navorsing (literatuurstudie, empiriese navorsing en die verslag) is gedoen deur R.P., onder leiding van B.J. d.K. en C.A.Y. B.J. d.K. het die literatuurstudie van die basisteoretiese perspektiewe en die integrasie daarvan in die resultate, begelei. C.A.Y. het die literatuurstudie van die metateoretiese perspektiewe, die integrasie daarvan in die resultate, en die empiriese navorsing, begelei.

\section{Litteratuurverwysings}

Bergner, R.M., 2005, 'Lovemaking as a ceremony of accreditation' [Hofmakery as akkrediteringseremonie], Journal of Sex and Marital Therapy 31(3), 425-432. http://dx.doi.org/10.1080/00926230591006773, PMid:16169825

Bevcar, D.S. \& Bevcar, R.J., 2002, Family therapy: A systemic integration, 5th edn., Allyn \& Bacon, Boston.

Botes, A., 2003, 'Validity, reliability and trustworthiness: To sum up', in D. Rossouw (ed.), Intellectual tools: Skills for the human sciences, 2 nd edn., pp. 176-184, Van Schaik, Pretoria.

Brown, J.H. \& Brown, C.S., 2002, Marital therapy: Concepts and skills for effective practice, Brooks/Cole, Pacific Grove.

Casaleggio, E. \& Van Rensburg, J., 2002, 'Die ontwerp van 'n terapeutiese model vir die pastorale seksuologie', Nederduitse Gereformeerde Teologiese Tydskrif 43(3\&4), 368-375.

Chapman, G.D., 2005, The 5 sides of intimacy. Hint: it's more than just sex, viewed 23 April 2009, from http://www.christianitytoday.com/mp/2005/fall/13.24 html?start=2

Chell, R.M., 2001, 'The role of househusband and housewife as perceived by college population' [Die rol van huisman en huisvrou: Waarneming deur kollegegemeenskap], Journal of Psychology, 135(6), 33-43.

Collins, G.R., 2005, Die A tot $Z$ van berading: Die mees omvattende gids, Struik Christelike boeke, Kaapstad.

Craig, E. \& Stander, H., 2008, A tot Z van seks: 'nSeksuele verhouding met jou huweliksmaat soos God dit bedoel het, Carpe Diem Media, Vanderbijlpark.

De Klerk, B.J., 2001, Soeklig: Fokus op Efesiërs, Die deputate Jeugsorg van die Nasionale Sinode GKSA, Potchefstroom.

De Klerk, P.B., 1997, 'Die huwelik as MUSTERION: Die etiese implikasies van Efesiërs $5: 21-33$ en veral van vers 32 ', M.Th-verhandeling, Fakulteit Teologie, PU vir CHO, Potchefstroom.

De Wet, F.W., 2009, Studiegids Pastoraal: Bybelse berading (Past 121), NoordwesUniversiteit, Potchefstroom

Epstein, N.B., Ryan, C.E., Bishop, D.S., Miller, I.W. \& Keitner, G.I., 2003, 'The McMaster model: A view of healthy family functioning', in F. Walsh (ed.), Normal family processes: Growing diversity and complexity, 3rd edn., pp. 581-607, Guilford Press, New York. http://dx.doi.org/10.4324/9780203428436_chapter_21

Haavio-Mannila, E. \& Kontura, O., 1997, 'What increases sexual satisfaction?' [Wat verhoog seksuele bevrediging?], Archives of Sexual Behavior 26(4), 399-419. http://dx.doi.org/10.1023/A:1024591318836, PMid:9251837

Hawkes, G., 2001, 'Liberalizing heterosexuality?', in G. Allan (ed.), The Sociology of the family: A reader, pp. 35-55, Blackwell, Oxford.

Hawkes, G., 2002, Sociology of sex and sexuality, Open University Press, Maidenhead, Philadelphia.

Holtzworth-Munroe, A. \& Jacobson, N.S., 1991, 'Behavioral marital therapy', in A.S. Gurman \& D.P. Kniskern (eds.), Handbook of family therapy, pp. 96-133, Brunner/ Mazel Publishers, New York.

Hopf, C., 2004, 'Research ethics and qualitative research', in U. Flick, E. von Kardorff, \& I. Steinke (eds.), A companion to qualitative research, pp. 334-339, Sage, London.

Kowal, S. \& O'Connell, D., 2004, 'The transcription of conversations', in U. Flick, E. von Kardorff \& I. Steinke (eds.), A companion to qualitative research, pp. 248-252, Sage, London.

LaHaye, T. \& LaHaye, B., 2003, The act of marriage, 3rd edn., p. 293, Christian Art, Vereeniging.

Lieser, M.L., Tambling, R.B., Bischof, G.H. \& Murry, N., 2007, 'Inclusion of sexuality in relationship education programs' [Die insluiting van seksualiteit in verhoudingsopvoedingsprogramme], The Family Journal: Counseling and Therapy for Couples and Families 15(4) 374-380. http://dx.doi. and Therapy for Couples and
org/10.1177/1066480707304948

Litzinger, S. \& Gordon, K.C., 2005, 'Exploring relationships among communication, sexual satisfaction and marital satisfaction [Bepaling van die verhouding tussen kommunikasie, seksuele bevrediging en huwelikstevredenheid]', Journal of Sex \& Marital Therapy 31(3), 409-424. http://dx.doi.org/10.1080/00926230591006719, PMid:16169824

Louw, D., 2004, Liefde is vir altyd: 'n Huweliksgids vir verloofdes en getroudes, 4e dr, Lux Verbi, Wellington.

Masters, W.H., Johnson, V.E. \& Kolodny, R.C., 1992, Human sexuality, 4th edn., Harper Collins, New York.

Ney, P.G., 2002, The importance of sex in a Christian marriage: A male perspective, viewed 07 February 2011, from http://www.messengers2.com/articles/marriage/ sex_in_a_christian marriage.pdf 
Poggenpoel, M., 2003, 'The research interview', in D. Rossouw (ed.), Intellectual tools: Skills for the human sciences, 2nd edn., pp. 143-149, Van Schaik, Pretoria.

Rodgers, R.H., 1973, Family interaction and transaction: The developmental approach, Prentice Hall, Englewood Cliffs.

Rosen, R. \& Bachmann, G.A., 2008, 'Sexual well-being, happiness, and satisfaction in women: The case for a new conceptual paradigm' [Seksuele welstand, geluk en bevrediging by vroue: 'n nuwe konseptuele paradigma], Journal of Sex and Marital Therapy 34(2) 291-297. http://dx.doi.org/10.1080/00926230802096234, PMid:18576229

Rosenau, D.E., 2002, A celebration of sex: A guide to enjoying God's gift of sexual intimacy, Thomas Nelson, Nashville.

Ryen, A., 2004, 'Ethical issues', in C. Seale, G. Gobo, J.F. Gubbrium \& D. Silverman (eds.), Qualitative research practice, pp. 230-247, Sage, London. http://dx.doi. org/10.4135/9781848608191.d20

Santtila, P., Wager, I., Witting, K., Harlaar, N., Jern, P., Johansson, A., Varjonen M. \& Sandnabba, K., 2008, 'Discrepancies between sexual desire and sexual activity: Gender differences and associations with relationship satisfaction' [Wanverhouding tussen seksuele begeerte en seksuele aktiwiteit: Geslagsverskille en assosiasie met verhoudingstevredenheid], Journal of Sex and Marital Therapy 34(1), 31-44. http://dx.doi.org/10.1080/00926230701620548
Schaefer, M.T. \& Olson, D.H., 1981, 'Assessing intimacy: The PAIR inventory' [Assessering van intimiteit: Die PAIR-inventaris], Journal of Marital and Family Therapy 7(1), 47-60. http://dx.doi.org/10.1111/j.1752-0606.1981.tb01351.x

Schmidt, C., 2004, 'The analysis of semi-structured interviews', in U. Flick, E. von Kardorff \& I. Steinke (eds.), A companion to qualitative research, pp. 253-258, Sage, London.

Shenton, A.K., 2004, 'Strategies for ensuring trustworthiness in qualitative research projects' [Strategieë om ' $n$ vertrouensverhouding in kwalitatiewe navorsingsprojekte te verseker], Education of Information 22(1), 63-75.

Sprecher, S., 2002, 'Sexual satisfaction in premarital relationships: Associations with satisfaction, love, commitment, and stability' [Seksuele bevrediging in voorhuwelikse verhoudings: Die verband tussen bevrediging, liefde, verbintenis en stabiliteit], The Journal of Sex Research 39(3), 190-196. http://dx.dol org/10.1080/00224490209552141, PMid:12476266

Terre Blanche, M., Durrheim, K. \& Painter, D., 2006, Research in practice: Applied methods for social sciences, 2nd edn., University of Cape Town Press, Cape Town.

Uys, T. \& Puttergill, C., 2003, 'Sampling', in D. Rossouw (ed.), Intellectual tools: Skills for the human sciences, 2nd edn., pp. 107-116, Van Schaik, Pretoria.

Venter, C.A., 1996, 'Huweliksverryking: 'n Sielkundige perspektief', in F. Swanepoel (ed.), Die huwelik, bl. 72-75, C.B. Powell-Bybelsentrum, Pretoria. 